\title{
Referaten
}

\section{Vooropleiding van invloed op studie- stijl en loopbaan van studenten geneeskunde}

\author{
McManus IC, Richards P, Winder BC. Intercalated \\ degrees, learning styles, and career preferences: pro- \\ spective longitudinal study of UK medical students. \\ British Medical Journal 1999;319:542-6. \\ Biggs JB. Study process questionnaire: manual. \\ Melbourne: Australian Council for Educational \\ Research; 1987.
}

Niet alleen in Nederland speelt de vraag welk ontwikkelingsniveau het beste zou zijn bij het begin van de studie geneeskunde. De recente keuze voor een voorkeurspositie bij de loting van studenten met een hoog gemiddeld eindexamencijfer is mede gebaseerd op het idee dat betere vwo-leerlingen ook betere wo-studenten zouden zijn. Juist bij geneeskunde is vaak gesteld dat ook motivatie en doorzettingsvermogen een belangrijke factor zouden kunnen zijn bij het met succes voltooien van de studie.

In het Verenigd Koninkrijk is er weliswaar een eindexamen, maar leerlingen kunnen uitbreidingen van hun pakket volgen, die uiteindelijk op een BSc-niveau uitkomen. Steeds meer opleidingen (Oxford, Cambridge, Nottingham) gaan deze zogenaamde 'intercalated studies' verplicht stellen als toegangseis voor hun 'medical school'.

In een bijzonder fraaie studie hebben McManus et al. onderzocht of er een invloed was van zo'n intercalated study op studiegedrag en specialisatiekeuze. Zij vroegen in 1990 en 1991 aan 6901 aanstaande geneeskundestudenten om een uitgebreide vragenlijst in te vullen. In 1996 en 1997, drie maanden voor het afstuderen van de studenten, werd opnieuw een lijst ingevuld (de studieprocesvragenlijst volgens Biggs, 1987). Deze lijst maakt onderscheid in de stijl van studeren (oppervlakkig, diep), motivatie (snel klaar zijn, interesse in een onderwerp, begrip) en studiestrategie (competitie, persoonlijk succes).

Wat de leerstijl betreft bleken de hoger opgeleide studenten significant minder oppervlakki- ge aspecten te hebben dan de minder opgeleide studenten en ze behaalden significant hogere resultaten. Aan het einde van de studie hadden ze significant hogere scores in diepgang en strategisch studeren.

De hoger opgeleide studenten hadden al aan het begin van de studie een voorkeur om later verder te gaan in de research en liever niet naar een algemene praktijk. Dit beeld bleef gedurende de gehele studie bestaan.

J.R.E. Haalboom, UMC Utrecht.

\section{Studeerstrategieën en leerstijlen; geen eenduidige zaak}

Beishuizen JJ, Stoutjesdijk ET. Study strategies in a computer assisted study environment. Learning and Instruction 1999;9(3):281-301.

Binnen de Universiteit Leiden is een computerondersteunde studeeromgeving (CASE) ontworpen met behulp waarvan studeerproblemen van studenten gediagnostiseerd kunnen worden. Beishuizen en Stoutjesdijk hebben onderzocht in hoeverre de verschillende informatiebronnen over leerstijlen en studiestrategieën, geïmplementeerd in deze studeeromgeving, uitsluitsel geven over oorzaken van studeerproblemen.

In het onderzoek werd een tekst over de theorie van Freud in CASE aangeboden aan 41 eerstejaars psychologiestudenten. Van deze groep beschikten 21 studenten over een oppervlakkige leerstijl en 20 studenten over een leerstijl gericht op gestructureerd en diepgaand verwerken van informatie ('diepgaande' leerstijl). Studenten werden aselect over twee onderzoekscondities verdeeld. De eerste groep kreeg de opdracht zich voor te bereiden op een toets met multiple-choice vragen terwijl de tweede groep zich moest voorbereiden op een toets met essayvragen. Na oriëntatie op de tekst en de studietaak maakten studenten een planning. De resterende tijd werd besteed aan het bestuderen van de tekst. 